\title{
Efficacy of analgesic effect of low dose intrathecal clonidine as adjuvant to bupivacaine in urogenital surgeries: study in a Kashmiri population
}

\author{
Zahoor Ahmad Shah 1 , Raksha Kundal', *Arun Kumar Gupta ${ }^{3}$,Mohd Sadiq Malla ${ }^{4}$ Faisal Zahoor \\ Vijay Kundal $^{6}$ Sameena Ashraf Kirmani ${ }^{7}$, Shigufta Qazi ${ }^{8}$ \\ Additional Professor ${ }^{1}$, Resident $^{2}$, Assistant Professor $^{3}$, Senior Resident $^{4}$, Resident $^{5}$, Professor \& Head ${ }^{8}$ \\ Dept. of Anesthesiology \& Critical Care, SKIMS, Srinagar, Jammu \& Kashmir India, Resident ${ }^{5}$, Dept. of \\ Emergency Medicine, Apollo Hospital, New Delhi, Senior Resident ${ }^{6}$, Dept. of Paediatric Surgery, SMS \\ Hospital, Jaipur, India
}

*Corresponding author: guptaarun71@gmail.com

Key words: bupivacaine, clonidine, intrathecal

\begin{abstract}
Background:
Previous studies have shown that clonidine given intrathecally in higher doses cause side effects. In this study, we used low dose clonidine intrathecally $(1 \mu \mathrm{g} / \mathrm{kg})$ as adjuvant to bupivacaine to study efficacy of analgesia and side effects.
\end{abstract}

\begin{abstract}
Method:
60 patients were randomly divided into two groups of 30 patients each. They were aged 20 to 60 years, of ASA Class I and II undergoing genitourinary surgeries. The clonidine group (A) received $1 \mu \mathrm{g} / \mathrm{kg}$ clonidine in addition to bupivacaine $12.5 \mathrm{mg}(0.5 \%)$ and control group (B) received an identical volume of saline mixed with $12.5 \mathrm{mg}(0.5 \%)$ bupivacaine. Efficacy of spinal analgesia was compared between these two groups.
\end{abstract}

\section{Results:}

Duration of analgesia, motor block, highest level of sensory block and time taken for regression of sensory analgesia by two segments was more in the clonidine group. There was a reduction in heart rate and systolic blood pressure which was statistically insignificant. Side effects like nausea and sedation were insignificant.

\section{Conclusion:}

Addition of low dose clonidine $(1 \mu \mathrm{g} / \mathrm{kg})$ to bupivacaine increases the duration of spinal analgesia as compared to bupivacaine alone with clinically insignificant influence on haemodynamic parameters and level of sedation.

Various agents such as opioids, clonidine, ${ }^{1}$ ketamine, neostigmine and midazolam ${ }^{2}$ are used as adjuvants to bupivacaine for spinal analgesia. Although opiods are the most commonly used they have disadvantages such as delayed respiratory depression, pruritus and postoperative nausea and vomiting. ${ }^{3}$

Intrathecal clonidine has proven to be a potent analgesic, free of at least some of the opiod related side effects ${ }^{4}$. It has been used as the sole anaesthetic agent as well as admixed with opiods and local anaesthetic in labour analgesia and orthopaedic surgery. Clonidine prolongs the duration of intrathecally administered local anaesthetics and has potent antinociceptive properties. ${ }^{5}$ Although such prolongation of the effect of local anaesthetics has been reported for oral $^{6,7}$ and intravenous ${ }^{8}$ clonidine administration, the intrathecal route is more effective in prolonging bupivacaine spinal anaesthesia ${ }^{9,10}$.The optimal dose in adults in terms of effects versus side effects of intrathecal clonidine is controversial. ${ }^{11,12,13}$

The present study was done to assess the analgesic effect of clonidine in low doses i.e. $1 \mu \mathrm{g} / \mathrm{kg}$ body 
weight, added to $0.5 \%$ intrathecal bupivacaine (heavy), in patients undergoing urogenital surgeries.

\section{Materials and Methods}

With the approval of the Hospital Ethics Committee and written informed consent of the patient, 60 patients (randomly divided into two groups of 30 each) aged 20 to 60 years and ASA Class I and II undergoing genitourinary surgeries like TURP, lower ureteric stones for endoscopy were included in the study. Patients with heart rate less than 60, systolic blood pressure less than 100 and history of uncontrolled hypertension, cardiac disease and allergy to any of the study drugs were excluded. This was a prospective, randomized double blind study. A pre anaesthetic visit was made. Preloading was done with $15 \mathrm{ml} / \mathrm{kg}$ dextrose saline about 15 minutes before lumbar puncture with a 25Gauge spinal needle as per institutional policy. Patients in the clonidine group (A) received a single dose of $12.5 \mathrm{mg}$ of $0.5 \%$ bupivacaine (heavy) plus $1 \mu \mathrm{g} / \mathrm{kg}$ preservative free clonidine $(150 \mu \mathrm{g} / \mathrm{ml})$ and the patients in the control group (B) were given $12.5 \mathrm{mg}$ of $0.5 \%$ bupivacaine (heavy) mixed with an identical volume of saline to keep the volume of the drug identical in the two groups.

Person administering the drug and persons making observations were kept blinded to the solution administered. The following observations were made: highest dermatomal level, time for first two segment regression, duration of surgery, analgesia, and motor blockade (modified Bromage scale).

The heart rate (HR), blood pressure, ECG, respiratory rate, and $\mathrm{SpO} 2$ were monitored at five minute intervals. Patients were observed for any discomfort, nausea, vomiting, shivering, pain, bradycardia and any other side effect and need for additional medications.

A reduction in mean arterial pressure (MAP) to less than $70 \mathrm{~mm} \mathrm{Hg}$ was treated with rapid infusion of $500 \mathrm{ml}$ of $0.5 \%$ dextrose saline and $3 \mathrm{mg}$ aliquots of mephentamine i.v. HR $<20 \%$ of baseline was treated with atropine $0.6 \mathrm{mg}$ i.v. Nausea and vomiting was treated with metaclopramide $10 \mathrm{mg}$ i.v. $\mathrm{O}_{2}$ saturation of less than $90 \%$ on atmospheric air and respiratory rate of $\leq 10$ per min was used to define respiratory depression. Severity of pain was measured using a $10 \mathrm{~cm}$ visual analogue scale at hourly intervals for the next $24 \mathrm{hrs}$ by nursing staff unaware of the group the patient belonged to. Rescue analgesia was provided with diclofenac sodium $75 \mathrm{mg}$ i.m. and frequency of administration noted. The statistical analysis of the data was done by using Student's t-test. Chi-square test and Fisher's Exact test were used to determine the nominal statistical analysis.

\section{Results}

There was no significant difference between the two groups with respect to age and sex distribution ( $>0.05)$ as shown in Table1.

Table 1: Demographic pattern

\begin{tabular}{|lll|}
\hline & Group A & Group B \\
Age(yrs) & $46.90 \pm 11.73$ & $45.93 \pm 13.80$ \\
Sex M:F & $25: 5$ & $29: 1$ \\
\hline
\end{tabular}

Haemodynamic parameters were comparable and statistically insignificant ( $>0.05$ ) except systolic blood pressure which showed a significant fall at 50mins (Table 2)

Table 2: Comparison of haemodynamic parameters

\begin{tabular}{|c|c|c|c|c|c|c|}
\hline \multirow[b]{2}{*}{$\begin{array}{l}\text { Heart } \\
\text { rate } \\
\text { (beats/ } \\
\text { min) }\end{array}$} & \multicolumn{2}{|c|}{ Heart rate in $\mathrm{mts}$} & \multicolumn{2}{|c|}{$\begin{array}{l}\text { Systolic blood } \\
\text { pressure in } \mathrm{mm} \mathrm{Hg}\end{array}$} & \multicolumn{2}{|c|}{$\begin{array}{l}\text { Diastolic blood } \\
\text { pressure in } \mathrm{mm} \mathrm{Hg}\end{array}$} \\
\hline & $\begin{array}{l}\text { Group A } \\
\text { Mean } \\
\pm \text { SD }\end{array}$ & $\begin{array}{l}\text { Group B } \\
\text { Mean } \\
\pm \text { SD }\end{array}$ & $\begin{array}{l}\text { Group A } \\
\text { Mean } \\
\pm S D\end{array}$ & $\begin{array}{l}\text { Group B } \\
\text { Mean } \\
\pm S D\end{array}$ & $\begin{array}{l}\text { Group A } \\
\text { Mean } \\
\pm S D\end{array}$ & $\begin{array}{l}\text { Group } \\
\text { B } \\
\text { Mean } \\
\pm S D\end{array}$ \\
\hline $\begin{array}{l}\text { Base } \\
\text { line }\end{array}$ & $\begin{array}{l}82.06 \\
\pm 13.07\end{array}$ & $\begin{array}{l}80.33 \\
\pm 9.18\end{array}$ & $\begin{array}{l}124.53 \\
\pm 9.68\end{array}$ & $\begin{array}{l}126 \\
\pm 11.23\end{array}$ & $\begin{array}{l}77.00 \\
\pm 5.96\end{array}$ & $\begin{array}{l}79.20 \\
\pm 5.86\end{array}$ \\
\hline $\begin{array}{l}\text { At } 1 \\
\min \end{array}$ & $\begin{array}{l}81.10 \\
\pm 12.90\end{array}$ & $\begin{array}{l}78.97 \\
\pm 9.12\end{array}$ & $\begin{array}{l}122.27 \pm \\
9.59\end{array}$ & $\begin{array}{l}125 \\
\pm 9.42\end{array}$ & $\begin{array}{l}75.17 \\
\pm 5.41\end{array}$ & $\begin{array}{l}75.90 \\
\pm 5.56\end{array}$ \\
\hline $5 \min$ & $\begin{array}{l}82.30 \\
\pm 11.80\end{array}$ & $\begin{array}{l}79.17 \\
\pm 9.00\end{array}$ & $\begin{array}{l}120.06 \pm \\
10.32\end{array}$ & $\begin{array}{l}121 \\
\pm 10.82\end{array}$ & $\begin{array}{l}74.20 \\
\pm 6.18\end{array}$ & $\begin{array}{l}77.07 \\
\pm 6.23\end{array}$ \\
\hline $10 \mathrm{~min}$ & $\begin{array}{l}83.46 \\
\pm 11.75\end{array}$ & $\begin{array}{l}79.96 \\
\pm 9.27\end{array}$ & $\begin{array}{l}120.07 \pm \\
10.78\end{array}$ & $\begin{array}{l}121 \\
\pm 10.03\end{array}$ & $\begin{array}{l}7413 \\
\pm 6.19\end{array}$ & $\begin{array}{l}76.27 \\
\pm 5.43\end{array}$ \\
\hline $15 \mathrm{~min}$ & $\begin{array}{l}82.70 \\
\pm 11.39\end{array}$ & $\begin{array}{l}79.60 \\
\pm 9.61\end{array}$ & $\begin{array}{l}120.87 \pm \\
9.29\end{array}$ & $\begin{array}{l}121 \\
\pm 9.21\end{array}$ & $\begin{array}{l}75.20 \\
\pm 5.67\end{array}$ & $\begin{array}{l}77.13 \\
\pm 4.92\end{array}$ \\
\hline $20 \mathrm{~min}$ & $\begin{array}{l}81.60 \\
\pm 10.96\end{array}$ & $\begin{array}{l}79.75 \\
\pm 1.06\end{array}$ & $\begin{array}{l}121.20 \pm \\
8.06\end{array}$ & $\begin{array}{l}120 \\
\pm 9.58\end{array}$ & $\begin{array}{l}75.71 \\
\pm 5.32\end{array}$ & $\begin{array}{l}76.38 \\
\pm 5.42\end{array}$ \\
\hline $25 \mathrm{~min}$ & $\begin{array}{l}80.55 \\
\pm 10.66\end{array}$ & $\begin{array}{l}80.00 \\
\pm 11.27\end{array}$ & $\begin{array}{l}120.55 \pm \\
7.87\end{array}$ & $\begin{array}{l}121 \\
\pm 8.39\end{array}$ & $\begin{array}{l}75.17 \\
\pm 5.41\end{array}$ & $\begin{array}{l}75.90 \\
\pm 5.56\end{array}$ \\
\hline $30 \mathrm{~min}$ & $\begin{array}{l}80.77 \\
\pm 10.48\end{array}$ & $\begin{array}{l}80.10 \\
\pm 11.26\end{array}$ & $\begin{array}{l}121.54 \pm \\
7.66\end{array}$ & $\begin{array}{l}119 \\
\pm 9.07\end{array}$ & $\begin{array}{l}76.77 \\
\pm 5.63\end{array}$ & $\begin{array}{l}76.32 \\
\pm 6.51\end{array}$ \\
\hline $40 \mathrm{~min}$ & $\begin{array}{l}78.64 \\
\pm 8.71\end{array}$ & $\begin{array}{l}82.00 \\
\pm 12.51\end{array}$ & $\begin{array}{l}121.23 \pm \\
7.68\end{array}$ & $\begin{array}{l}122 \\
\pm 9.09\end{array}$ & $\begin{array}{l}75.85 \\
\pm 6.66\end{array}$ & $\begin{array}{r}79.33 \\
\pm 6.48\end{array}$ \\
\hline $50 \mathrm{~min}$ & $\begin{array}{l}80.80 \\
\pm 8.79\end{array}$ & $\begin{array}{l}84.25 \\
\pm 13.47\end{array}$ & $\begin{array}{l}127.60 \pm \\
7.67\end{array}$ & $\begin{array}{l}116 \\
\pm 5.16\end{array}$ & $\begin{array}{l}79.20 \\
\pm 6.42\end{array}$ & $\begin{array}{l}76.00 \\
\pm 6.20\end{array}$ \\
\hline $60 \mathrm{~min}$ & $\begin{array}{l}79.00 \\
\pm 15.56\end{array}$ & $\begin{array}{l}73.80 \\
\pm 10.92\end{array}$ & $\begin{array}{l}122.00 \pm \\
2.83\end{array}$ & $\begin{array}{l}115 \\
\pm 5.77\end{array}$ & $\begin{array}{l}75.00 \\
\pm 7.07\end{array}$ & $\begin{array}{l}77.00 \\
\pm 4.76\end{array}$ \\
\hline $\begin{array}{l}\text { At the } \\
\text { end }\end{array}$ & $\begin{array}{l}81.07 \\
\pm 10.79\end{array}$ & $\begin{array}{l}78.57 \\
\pm 10.47\end{array}$ & $\begin{array}{l}121.60 \pm \\
9.06\end{array}$ & $\begin{array}{l}119 \\
\pm 8.99\end{array}$ & $\begin{array}{l}76.00 \\
\pm 5.78\end{array}$ & $\begin{array}{l}76.66 \\
\pm 5.64\end{array}$ \\
\hline
\end{tabular}


Duration of surgery was comparable.

The level of sensory block, time for 2 segment regression, motor block, duration of analgesia were all greater in the clonidine group $(\mathrm{P}<0.005)$. (Table 3)

Table 3: Side effects showed no difference

\begin{tabular}{|lll|}
\hline & Group A & Group B \\
Duration of surgery(min) & $33.6 \pm 9.60$ & $32.66 \pm 14.06$ \\
$\begin{array}{l}\text { Highest sensory level T6; T8; } \\
\text { T9;T12. }\end{array}$ & $40 ; 46 ; 10 ; 3$ & $16 ; 40 ; 36 ; 6$ \\
$\begin{array}{l}\text { Regression of sensory block } \\
\text { by 2 segments(min) }\end{array}$ & $190.00 \pm 39.65$ & $121.96 \pm 27.80$ \\
$\begin{array}{l}\text { Duration of motor block(min) } \\
\text { Analgesia time(min) }\end{array}$ & $219.40 \pm 86.27$ & $159.70 \pm 66.74$ \\
No of diclofenac injections & $1.47 \pm 0.57$ & $214.10 \pm 157.1$ \\
\hline
\end{tabular}

Table 4: Comparison of side effects in Group A and Group B

\begin{tabular}{|c|c|c|c|c|c|c|}
\hline \multirow[t]{2}{*}{ Side-effects } & \multicolumn{2}{|c|}{ Group A (study) } & \multicolumn{2}{|c|}{ Group B (control) } & \multirow[t]{2}{*}{$p$-value } & \\
\hline & $\begin{array}{l}\text { Present } \\
\text { (\%) }\end{array}$ & $\begin{array}{l}\text { Absent } \\
\text { (\%) }\end{array}$ & $\begin{array}{l}\text { Present } \\
\text { (\%) }\end{array}$ & $\begin{array}{l}\text { Absent } \\
\text { (\%) }\end{array}$ & & \\
\hline Nausea & $3(10.00)$ & $\begin{array}{l}27 \\
(90.00)\end{array}$ & $2(6.70)$ & $\begin{array}{l}28 \\
(93.30)\end{array}$ & 0.640 & NS \\
\hline $\begin{array}{l}\text { Mouth- } \\
\text { dryness }\end{array}$ & $3(10.00)$ & $\begin{array}{l}27 \\
(90.00)\end{array}$ & $2(6.70)$ & $\begin{array}{l}28 \\
(93.30)\end{array}$ & 0.640 & NS \\
\hline Sedation & $2(6.70)$ & $\begin{array}{l}28 \\
(93.30)\end{array}$ & $0(0.00)$ & $\begin{array}{l}30 \\
(100.00)\end{array}$ & 0.492 & NS \\
\hline $\begin{array}{l}\text { Respiratory } \\
\text { depression }\end{array}$ & $0(0.00)$ & $\begin{array}{l}30 \\
(100.00)\end{array}$ & $0(0.00)$ & $\begin{array}{l}30 \\
(100.00)\end{array}$ & 1.000 & NS \\
\hline Desaturation & $0(0.00)$ & $\begin{array}{l}30 \\
(100.00)\end{array}$ & $0(0.00)$ & $\begin{array}{l}30 \\
(100.00)\end{array}$ & 1.000 & NS \\
\hline
\end{tabular}

\section{Discussion}

Alpha-2 agonists act on adrenoreceptors in the spinal cord and block conduction of $\mathrm{C}$ and $\mathrm{A} \delta$ fibers, increasing potassium conductance and intensifies conduction block of local anaesthetics. Less than $150 \mu \mathrm{g}$ of clonidine has been shown to significantly prolong the anaesthetic and analgesic effect of bupivacaine in a dose depended manner. 12,14

Similar results were obtained when it was used as a sole analgesic during the first stage of labour but the high incidence of hypotension required caution with use of $200 \mu \mathrm{g} .{ }^{15}$ Increased doses of intrathecal clonidine have been associated with increased side effects ${ }^{5,15}$. This was the reason we chose a low dose of $1 \mu \mathrm{g} / \mathrm{kg} .{ }^{9,16}, 17,18$ in this study, and we found that the heart rates and blood pressures showed no significant differences between the two groups ${ }^{9,16,17}$ similar to other studies. In our study, the highest sensory level $\mathrm{p}$-value $=0.047$ and time taken for sensory regression by two segments was greater $(\mathrm{P}<0.05)$. This is in agreement with the results of other studies. ${ }^{5,9,17,19}$

In our study the duration of analgesia time (time to first complaint of pain) was significantly longer in study group.

Bupivacaine acts mainly by blockade of voltage gated $\mathrm{Na}+$ channel in the axonal membrane. It may also cause presynaptic inhibition of calcium channels and a combination of these effects may explain the observed synergism between bupivacaine and clonidine ${ }^{17,20,21}$. In this study, side effects like nausea and mouth dryness were found to be statistically insignificant. Sedation was encountered in only $6.7 \%$ of patient in study group and in none of the patients in group B and difference was statistically insignificant.

We found that side effects were minimal and showed no significant differences in the two groups perhaps due to the low dose used. Previous studies have shown that dose $<150 \mu g^{14}$ did not cause sedation while higher doses did.

\section{Conclusion}

We conclude that clonidine $1 \mu \mathrm{g} / \mathrm{kg}$ added to $2.5 \mathrm{ml}$ of $0.5 \%$ hyperbaric bupivacaine prolongs sensory spinal block, increases the duration of analgesia and motor block without causing significant side effects.

\section{References:}

1. Benhamou Dan, Thorin D et al. Intrathecal clonidine and fentanyl with hyperbaric Bupivacaine improves analgesia. Anesth Analg. 1998, 87(3):609-613.

2. D Bhattacharya, B. Biswas, et al. Intrathecal midazolam with Bupivcaine increases the analgesic effects of spinal blockade after major gynaecological surgery. $J$ Anaesthesiol Clin Pharmacol. 2002; 18:183-196. 
3. Gustafsson LL, Schildt B, Jackobson K. Adverse effects of extradural and intrathecal opiates: Report of a nationwide survey in Sweden. Br J Anaesth 1982; 54: 479-86.

4. Eisenach JC. Overview: First international symposium on alpha 2 adrenergic mechanisms of spinal anaesthesia. Reg Anaesth 1993; 18 (4S): i-vi.

5. L Niemi. Effects of intrathecal clonidine on duration of Bupivcaine spinal anaesthesia heamodynamics and postoperative analgesia in pat undergoing knee arthroscopy. Acta Anaesthisol Scand. 1994; 38.724-8.

6. Liu S, Chiu AA, Neal JM, et al. Oral Clonidine prolonges lidocaine spinal anesthesia in human volunteers. Anesthesiolgy. 1995; 82:1353-9.

7. Ota K, Namiki, Iwasaki H, Takahashi J. Dose related prolongation of tetracaine spinal anesthesia. Anesth Analg 1994; 79:1121-5.

8. Rhee K, Kang K, Kim J, Jean Y. Intravenous clonidine prolonges Bupivacaine spinal anesthesia. Acta Anaesthesiol Scand. 2003;47:1001-5.

9. Drobrydnjov I, Axelsson K, Samarutel J, Holmstrom B. Postoperative pain relief following intrathecal bupivacaine combined with intrathecal or oral clonidine. Acta Anaesthesiol Scand. 2002: 46:806-14.

10. Bonnet F, Bursson VB, Francois Y, et al. Effects of oral and subarachnoid clonidine on spinal anesthesia with bupivacaine. Reg Anaesth. 1990; 15: 211-4.

11. Grace D, Bunting H, Milligan KR, Fee JP. Postoperative analgesia after co-administration of clonidine and morphine by intrathecal route in patients undergoing hip replacement surgery. Anaesth Analg. 1995; 80:86-91.

12. Chiari A, Lobar C, Eisenach J C, et al. Analgesic and haemodynamic effect of intrathecal clonidine as the sole analegesic agent during first stage of labour. Anesthesiology. 1999; 91:388-96.
13. Filos KS, Goudas LC, Patroni O, Polyzou V. Intrathecal clonidine as a sole analgesic for pain relief after caesarean section. Anesthesiology 1992; 77: 267-74

14. Stephan Strebl, Jurg A Gurzeler, et al. Isobaric Bupivcaine provide dose dependent and clinically significant prolongation of spinal anaesthesia and pain relief. Anesth Analg. 2004; 99:1231-1238.

15. Butter Worth JF, Strichartz GR. Molecular mechanisms of local anaesthesia: a review. Anesthesiology. 1990; 72:711-34.

16. De Negri P, Salvatore R, Visconti C, DeVivo P, Mastronardi P. Spinal anesthesia with clonidine and bupivacaine in young humans: interactions and effects on cardiovascular system. Minerva Anesthesiology 1997; 63: 119-25.

17. Olfa Kaabachi O, Zarghouni, et al. Clonidine 1 microgram $/ \mathrm{kg}$ is safe and effective adjuvant to to plain Bupivcaine in spinal anaesthesia in adolescent. Anesth Analg. 2007; 105:516-519.

18. Sia AT. Optimal dose of intrathecal Clonidine added to Sufentanil plus Bupivcaine for labour analgesia. Can J Anaesth. 2000;47(9):875-80.

19. Elia N,Culebras X, et al. Clonidine as an adjuvant to intrathecal local anaesthesia for surgery: systemic review of randomised trial. Reg Anesth Pain Med. (2008); 33(2):159-67.

20. Sethi BS, Samuel M, Sreevastava D. Efficacy of Analgesic Effects of Low Dose Intrathecal Clonidine as Adjuvant to Bupivacaine. Indian $J$ Anaesth 2007;51:415

21. van Tuijl I, van Klei WA, van der Werff DB, Kalkman CJ. The effect of the addition of Clonidine to hyperbaric Bupivcaine on postoperative pain and morphine requirements after caesarean section. $\mathrm{Br} \mathrm{J}$ Anaesth. 2006;97(3):365-70. 